\title{
ArcheoSciences
}

Revue d'archéométrie

33 (suppl.) | 2009

Mémoire du sol, espace des hommes

\section{Application of the space syntax to the study of city planning from Syrian Late Bronze Age circular cities}

\section{Sébastien Gondet and Christophe Benech}

\section{OpenEdition}

Journals

Electronic version

URL: https://journals.openedition.org/archeosciences/1606

DOI: 10.4000/archeosciences.1606

ISBN: 978-2-7535-1599-4

ISSN: $2104-3728$

Publisher

Presses universitaires de Rennes

\section{Printed version}

Date of publication: 30 October 2009

Number of pages: $217-219$

ISBN: 978-2-7535-0943-6

ISSN: $1960-1360$

\section{Electronic reference}

Sébastien Gondet and Christophe Benech, "Application of the space syntax to the study of city planning from Syrian Late Bronze Age circular cities", ArcheoSciences [Online], 33 (suppl.) | 2009, Online since 30 October 2011, connection on 01 February 2022. URL: http://journals.openedition.org/ archeosciences/1606; DOI: https://doi.org/10.4000/archeosciences.1606 


\title{
Application of the space syntax to the study of city planning from Syrian Late Bronze Age circular cities
}

\author{
Sébastien GondeT* and Christophe BenECH ${ }^{* *}$
}

Key words: Space syntax, City planning, Magnetic survey, Bronze Age, Syria.

Within a Syrian-French program entitled Emergence, organisation and expansion during the Late Bronze Age of the circular cities in the Syrian Jezireh area, two magnetic surveys have been carried out on Al-Rawda (Gondet and Castel, 2003) and Sheirat archaeological sites. This program deals with the emergence during the last phases of the Late Bronze Age of circular cities in the centre of the actual Syrian territory. Protected by large fortification ranges these cities were following a radio-concentric urbanism scheme. This emergence, of which Al-Rawda and Sheirat are two significant examples, ensues from a previous development of circular cities corresponding to the first urbanization phase of the Upper Euphrates region. Between these two expansion phases we notice a chronological gap of one or two centuries and particularly a cultural gap materialised by two very different ceramic types. Nevertheless presence of the characteristic anta temples in the two regions and appropriation of the circular plan could bear witness to a cultural melding made possible by long commercial exchanges. Excavations are being carried out at Sheirat and Al-Rawda whose aims are to refine the chronology and to get more accurate material and architectural data to determine differences and links between the two regions. In parallel, geophysical surveys have been carried out over the whole surface of both sites and have provided accurate data concerning their city planning allowing a better characterisation of the urban schemes of Late Bronze Age in central Syria.
Both sites presented good survey conditions: shallow remains; clear surface; restricted reoccupations after the Late Bronze Age main occupation period; limited modern perturbations or lootings. Moreover both sites present remains of building foundations made of limestone blocks which were used as basements for mud-brick superstructures. Given the clayey or silty sedimentary nature of the topsoil layer on both sites, these types of remains present good magnetic variations allowing accurate sensing. The Al-Rawda map presents a quite complete view of the Bronze Age city comprising its fortification system. Organized around a central ovoid area delimited by a large circular central road, the city shows a clearly visible radio-concentric urbanism scheme. However, urban dynamism corresponding to inner reorganisation of some city sectors and an expanding built area has partly modified the initial plan. This can be clearly illustrated for example by studying the street network of Al-Rawda. The plan of the network shows that inhabitants had designed a balanced circulation system with well distributed radial streets cutting three circular streets, one on the periphery, one around the central district and one roughly in the middle of the two others. The image obtained thanks to the geophysical investigations shows that this network has evolved, particularly the concentric roads system. In comparison, the case of Tell Sheirat seems more complex (Fig. 1). The city is wider and its urbanism scheme is less visible. This plan also exhibits a major difference when compared to Al-Rawda:

* PHD student, UMR 5133 Archéorient, CNRS, Université Lyon 2.

** UMR 5133 Archéorient, CNRS, Université Lyon 2. 


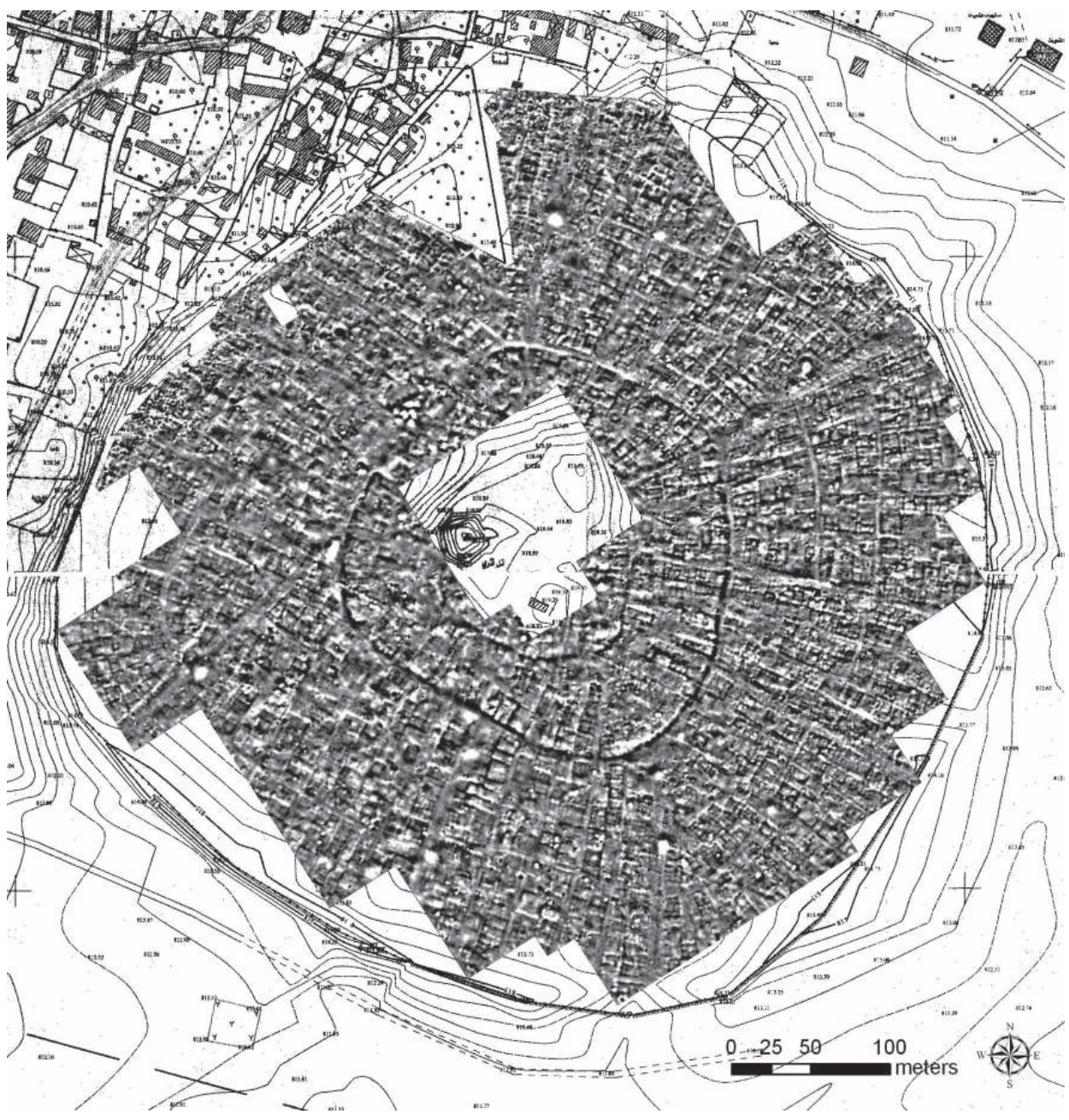

Figure 1: Magnetic gradient map obtained on tell Sheirat. at least one inner rampart enclosing the central part of the site. On a large part of the site, the radio-concentric model has been applied but we assess that topographic constraints have maybe affected the northwestern part of the city where an orthogonal organization appears. Due to a high building density indicating perhaps high urbanism dynamism, the road network is more difficult to plot. Nevertheless, as at Al-Rawda, we can delineate quite easily radial streets that the layouts have better resisted.

The Al-Rawda magnetic map offers a clear image of the street network on which it was possible to apply quickly studies using space syntax methods. Such an approach allows city planning to be studied beyond its theoretical conception and to recognize its practical realization and evolution throughout the occupation (Benech, 2007; Benech, under press).Two types of documents have been edited: axial map (Fig. 2) and visibility graph (Fig. 3).

The radial streets of Rawda are well preserved in terms of linearity and width, with a high connectivity as we can see on the axial map. Only the R3 street is less accessible near the centre. The other radial streets are generally dead ends, thus their role in the spatial organization of the streets network is different. They have a lower connectivity and are probably used more for direct access inside particular areas rather than links between different quarters. The shape of the circular street is more disturbed and highlights an important evolution of the concentric network. From centre to periphery, the oval shape of streets gradually tends to a more circular shape. The $\mathrm{C} 1$ street is still regular in its last state with an oval layout. This regularity may prove that its layout has been well preserved and therefore has never had a strictly circular shape. Moreover, the oval shape is also visible in the orientation of the walls of the central quarter of the town suggesting that this part of the city has all been planned at the same time with this oval shape. The layout of the $\mathrm{C} 2$ street is more fragmentary: the most well preserved parts are the east and west sections (which also exhibit good connectivity) with a layout near the oval shape of the $\mathrm{C} 1$ 


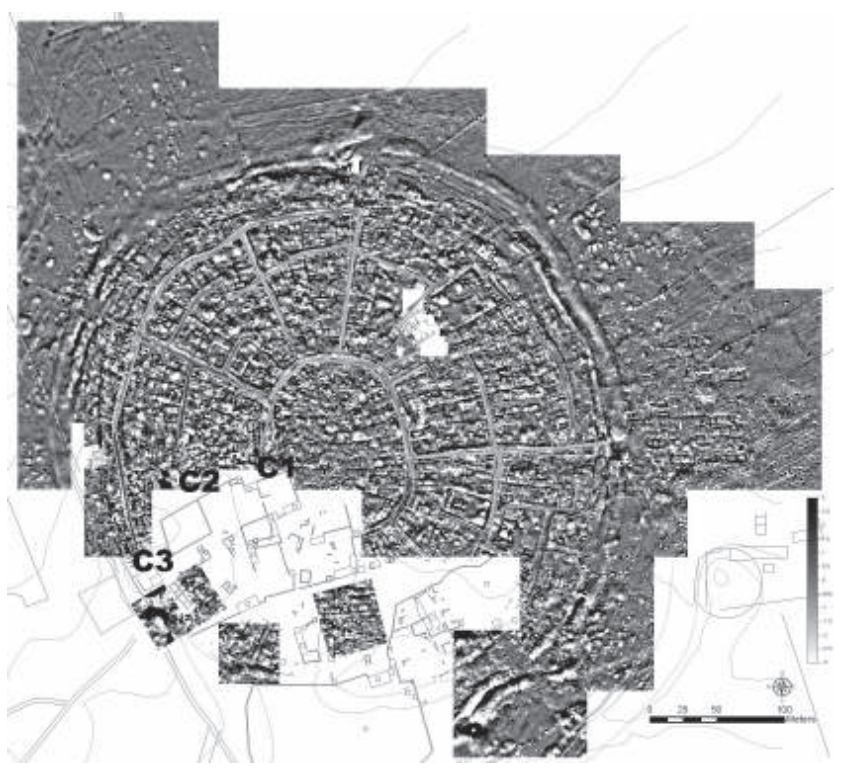

Figure 2 (see color plate): Visibility graph of the street network of tell Al-Rawda.

street. The layout of the C3 street is rather well preserved with a more circular shape than $\mathrm{C} 1$ and $\mathrm{C} 2$. Generally speaking, the connectivity of the axial map and visibility graph confirms the previous hypothesis of a better preserved radial network: connectivity values of radial streets are generally higher than circular ones. It shows the importance of the radial streets for the inner circulations.

For a more detailed interpretation extending these initial observations, it is obviously necessary to study the inner organization of the different quarters in conjunction with the information obtained from the axial maps and visibility graph analysis. For example, we can see that the northern part of the city planning is radically different from western and eastern parts. To the north, the street network has a higher density and seems have been deeply transformed during the occupation of the site. This evolution will probably be identifiable in the analysis of the spatial units: the denser network shows the necessity of a better distribution of the spatial units (domestic, public or religious) which are probably smaller than in the other sectors.

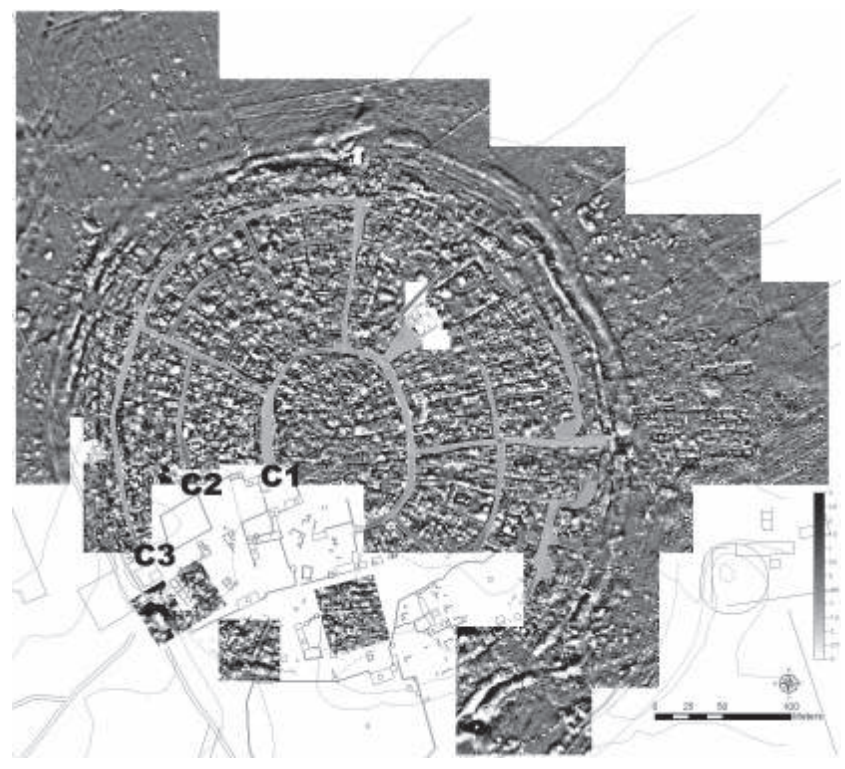

Figure 3 (see color plate): Connectivity graph of the street network of tell Al-Rawda.

\section{References}

Gondet, S. and CASTel, C., 2003. Prospection géophysique sur le site d'al-Rawda et urbanisme en Syrie au Bronze ancien. Paléorient, 30-2: 93-109.

BENECH, C., 2007. Study of Ancient City Planning with Axial Maps and Visibility Graph Analysis, Studijne zvesti Archeologickeho ustavu, SAV 41: 109-112.

BENECH, C., under press. The use of "space syntax" for the study of city planning and household from geophysical maps: the case of Dura-Europos (Syria, Acts of the conference "Urban Living in the eastern Mediterranean 4 th century BC - 1 st century AD”, Vienna, 24-27 October 2007. 